Ms. 4492

\title{
MYCORRHIZAL OCCURRENCE IN WILLOWS IN A NORTHERN FRESHWATER WETLAND
}

\author{
by PAUL E. MARSHALL and NANCY PATTULLO \\ School of Natural Resources, University of Michigan, \\ Ann Arbor, MI 48109
}

\section{KEY WORDS}

Ectomycorrhiza Flooding Michigan Peat Phosphorus Salix

\begin{abstract}
SUMMARY
Willows growing in a north central Michigan wetland were found to be ectomycorrhizal throughout the 1978 growing season on each of two sites (one water-saturated, one relatively drier). Each site was dominated by a mix of sedges (Carex spp.) and willows (Salix spp.). On both sites, phosphorus was added at two levels ( 20 or $200 \mathrm{~kg} \mathrm{P} \mathrm{ha}^{-1}$ ) to simulate potential inputs from the disposal of secondarily-treated municipal wastewater. The intensity of willow root infection was determined by scoring root tips on a 0 to 4 scale based on mantle-, intercellular hyphae-, and root epidermal cell characteristics.

Infection on the wet site remained uniformly heavy in July and August when $P$ was added, but it declined significantly during August for control plants at both sites. When water levels increased during September, the intensity of mycorrhizal infection increased on control plants on the wet site. On the drier site, mycorrhizal intensity decreased on controls and on plants exposed to the highest $P$ levels. Between August and September samplings, mycorrhizal intensity increased considerably on dry-site controls but did not change on plants exposed to added $\mathbf{P}$.
\end{abstract}

\section{INTRODUCTION}

The nutrient dynamics in freshwater wetland ecosystems have been of increasing interest since it was suggested that wetlands may function as nutrient traps to prevent eutrophication ${ }^{5,6}$ and since wetlands have become sites for disposal of secondarily-treated sewage effluent ${ }^{19}$. Phosphorus (P) dynamics in wetlands have been of particular interest since $\mathrm{P}$ is involved in a complex biogeochemical cycle which is poorly understood. Wetland plants may play an important role in $P$ cycling and numerous studies have described parts of phosphorus cycles in wetlands based in part on observed changes in $P$ concentrations in plant tissues, plant uptake of $\mathbf{P}$, and biomass changes ${ }^{9,16}$. Other studies have described wetland plant responses to applied $P^{12,20}$, however, very few studies of wetland nutrient dynamics have considered the occurrence or role of mycorrhizas. Others have suggested that as phosphorus concentrations increase in soils, the intensity 
of mycorrhiza formation decreases ${ }^{7}$. Since willows are one of the major woody plants in northern freshwater wetlands, and since little is known about wetland willow mycorrhizas, this study was initiated to observe seasonal changes in the occurrence and structure of willow mycorrhizas and to determine the effects of added phosphorus on wetland willow mycorrhizas.

\section{METHODS}

\section{Site description}

The study sites were located in a 716 ha fen southwest of Houghton Lake in Roscommon County, Michigan. This wetland was chosen as it has been the object of considerable ecological study $2,15,16,18,19,20$ and it is currently being used as a disposal site for secondarily-treated municipal wastewater. The vegetation and hydrologic characteristics of this wetland (fen) have been extensively described in the above references. A sedge and willow vegetation cover predominated on the sites used in this study, and peat soils ranged from 0.5 to $1.5 \mathrm{~m}$ in depth. The peat was underlain by sand and clay. Throughout the study, the pH of interstitial water ranged from 5.7 to 6.9 at a $25 \mathrm{~cm}$ depth and redox potentials ranged from -160 to $+10 \mathrm{mV}$ at $25 \mathrm{~cm}$ depths.

One study site was located in a relatively wet area where peat remained water-saturated throughout the summer. A second site was located at a slightly higher elevation and was somewhat drier such that water levels dropped to an average of $5 \mathrm{~cm}$ below the peat surface in mid-summer. Neither site was affected by other studies in progress on the wetland (sewage effluent additions, mainly).

Table 1. Effects of season, site, and phosphorus [20 (low) or 200 (high) kg P.ha ${ }^{-1}$ ] on wetland willow mycorrhizas*

\begin{tabular}{lccccccc}
\hline & \multicolumn{3}{c}{ Wet site } & & & \multirow{2}{*}{ Dry site } \\
\cline { 3 - 3 } \cline { 7 - 8 } & Control & Low P & High P & & Control & Low P & High P \\
\hline July & $2.71^{\mathrm{ab}}$ & $2.79^{\mathrm{ab}}$ & $2.83^{\mathrm{ab}}$ & & $2.96^{\mathrm{ab}}$ & $3.11^{\mathrm{ab}}$ & $3.20^{\mathrm{b}}$ \\
August & $1.86^{\mathrm{a}}$ & $2.60^{\mathrm{a}}$ & $3.00^{\mathrm{ab}}$ & & $1.25^{\mathrm{a}}$ & $2.20^{\mathrm{a}}$ & $2.00^{\mathrm{a}}$ \\
September & $3.30^{\mathrm{b}}$ & $3.25^{\mathrm{b}}$ & $3.30^{\mathrm{b}}$ & & $3.30^{\mathrm{b}}$ & $2.44^{\mathrm{a}}$ & $2.67^{\mathrm{ab}}$ \\
\hline
\end{tabular}

* Numbers represent mean scores of mycorrhizal intensity $(n>20)$. Scoring was based on the following scheme: $0=$ No intercellular or external hyphae observed in light- or electron microscopy. Roots determined to be nonmycorrbizal.

$1=$ Some external hyphae but very little intercellular penetration observed in light-and electron microscopy, but other indications of ectomycorrhiza not observed.

2 = Definite mantle observed in electron microscopy. Some intercellular hyphae visible in light microscopy, but not extensive.

3 = Definite mantle observed in electron microscopy. Considerable intercellular hyphae and slight epidermal cell elongation noted in light microscopy. Many more cortical cells surrounded by hyphae than in specimens given a 2 rating.

$4=$ Very organized mycorrhizas observed in light- and electron microscopy. Observations include thick and extensive mantle, extensive intercellular hyphae, and pronounced epidermal cell elongation.

Numbers with the same superscript letter are not significantly different $(p \leq 0.05)$. 


\section{Mycorrhizal assessment}

Roots from a single willow species were excavated and collected from each site at monthly intervals from May through September, 1978, and roots were prepared for immediate light microscopy using lactophenol ${ }^{13}$. Other root samples were fixed in FAA $^{8}$ and either thin-sectioned in paraffin and stained for light microscopy ${ }^{8}$ or dried by a critical-point method ${ }^{1}$, coated with gold-palladium, and viewed in the secondary emission mode of a JEOL JSM-U3 scanning electron microscope.

Mycorrhizal infection intensity was assessed by viewing root segments or cross-sections with lightor scanning electron microscopy. A numerical value was assigned to samples based on mantle-, hyphal-, and epidermal cell characteristics as described in Table 1. At least 20 root tips were scored for each sampling. Data were analyzed by using a Kruskal-Wallis one-way ANOVA ${ }^{17}$.

\section{Phosphorus addition}

Six plastic tubs ( $20 \mathrm{~cm}$ deep, $35 \mathrm{~cm}$ diameter) were buried on each study site and filled with excavated clumps of a single willow species in late May, 1978. Numerous small holes in the bottom of these tubs allowed water levels to fluctuate with those of the wetland. Phosphorus was added as $\mathrm{KH}_{2} \mathrm{PO}_{4}$ in solution to provide the following treatments: Low P-20 kg P.ha ${ }^{-1}$, high P-200 kg P.ha ${ }^{-1}$, and control - no $P$ added. A plexiglas tube was used to collect peat cores $(2 \mathrm{~cm}$ diameter, $20 \mathrm{~cm}$ depth) from each bucket at monthly intervals from July through September. Willow root tips were collected throughout the core and handled as described above.

\section{RESULTS AND DISCUSSION}

\section{Occurrence of willow mycorrhizae}

Although several studies have reported that flooded conifers and wetland plants in wet environments are generally non-mycorrhizal ${ }^{3,11,14}$, and although interstitial water at our study sites was very anaerobic as indicated by the negative redox potentials, we found willows in the Houghton Lake wetland to be consistently ectomycorrhizal throughout the growing season. Our findings are similar to those of Fontana ${ }^{4}$ who examined 14 species of willows in Italy and found all to be ectomycorrhizal, however Fontana did not observe wetland willows.

In this study, ectomycorrhizas collected from the continuously wet site in May and September had macro- and microscopic differences compared to those collected from the relatively drier site. Roots collected from the wet site generally had better Hartig net development and darker colored mantles than did roots from the drier site, although roots from both sites had thick mantles and elongated epidermal cells. Roots collected in July and August were not different with respect to site.

The intensity of mycorrhizal infection decreased somewhat in late summer (August) on roots from both sites, but it increased again in September as determined by scoring of root tips (Table 1, Controls). Some roots had extensive 
hyphal development in early fall (Fig. 1). Non-mycorrhizal root tips were most easily identified by use of the SEM at high magnification. In a number of cases, root segments appeared to be non-mycorrhizal at $200 \times$, but when viewed at $1000 \times$ or higher, a well-developed mantle with few protruding hyphae could be seen (Figs. 2A, B). At higher magnifications such mycorrhizal roots were easily distinguished from non-mycorrhizal roots (Fig. 2B). At least some of the fungi involved in willow mycorrhizae were Basidiomycetes as evidenced by the frequent presence of clamp connections (Fig. 3).

\section{Effects of added phosphorus}

Most roots in all treatments were ectomycorrhizal throughout the growing season, but ratings of the intensity of mycorrhizal infection varied significantly

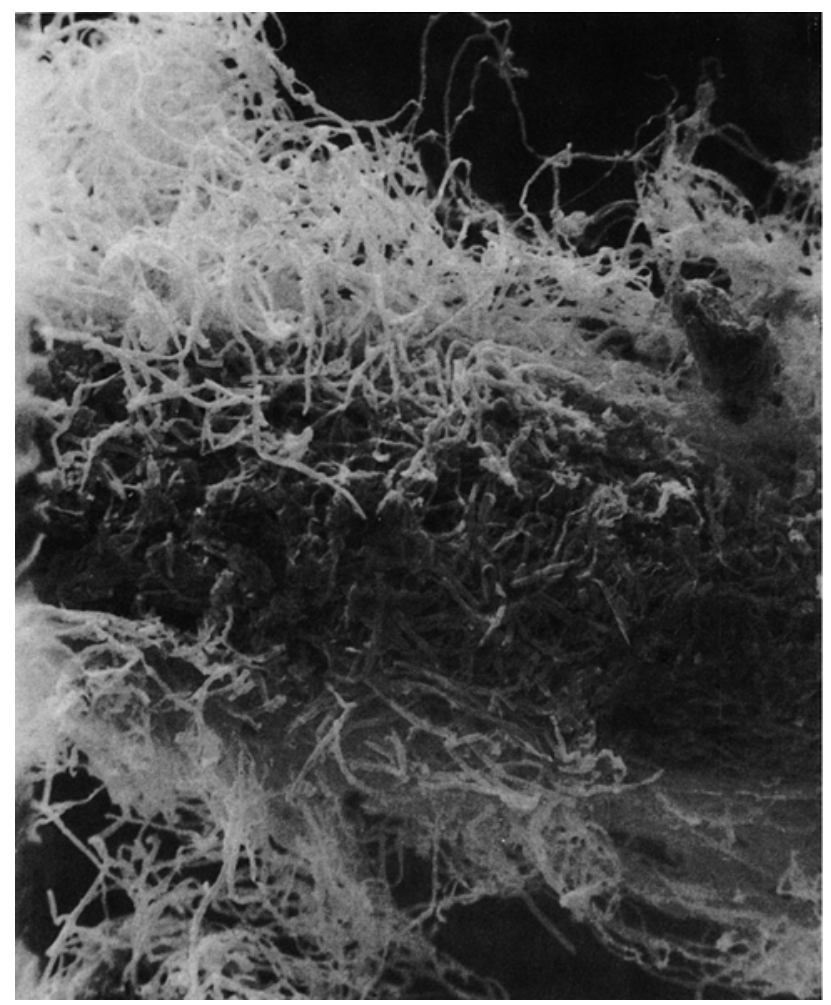

Fig. 1. Willow root showing extensive external hyphae; collected from the wet site in September $(300 \times)$. 


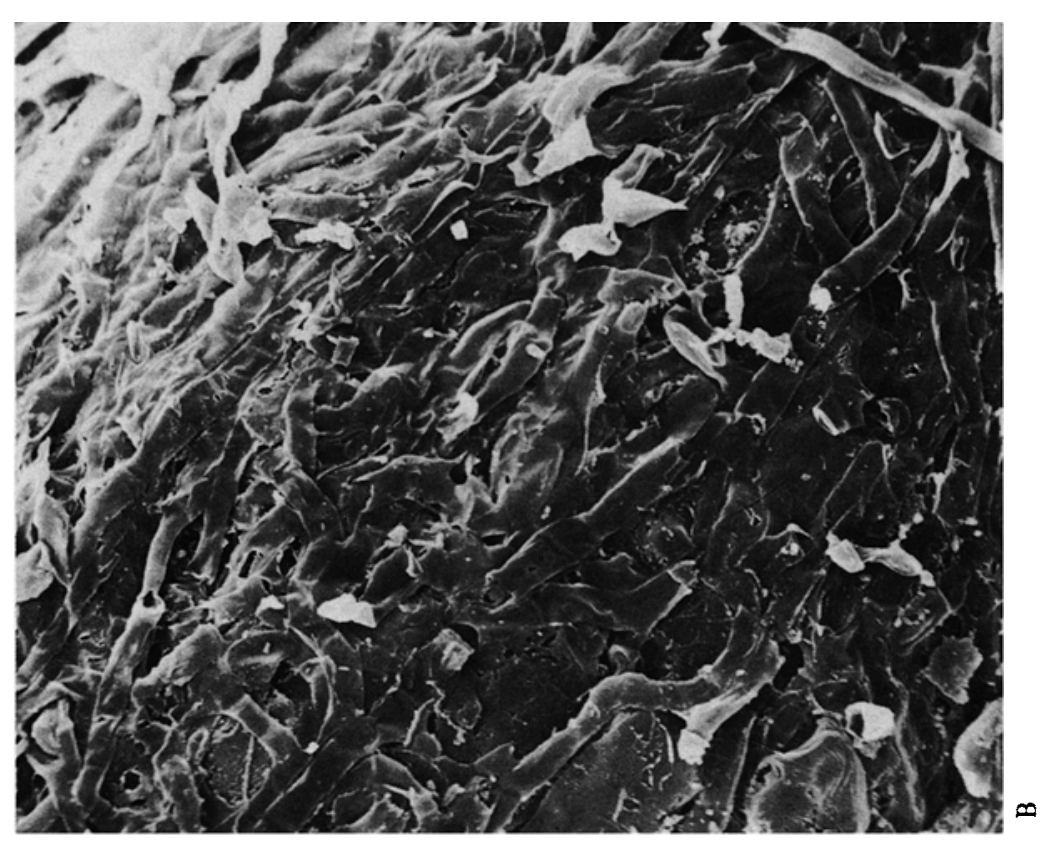

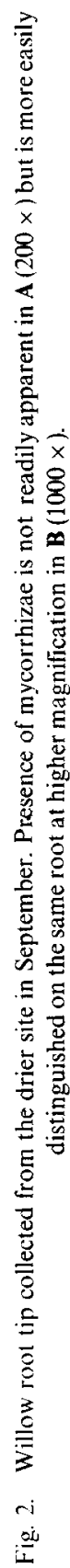

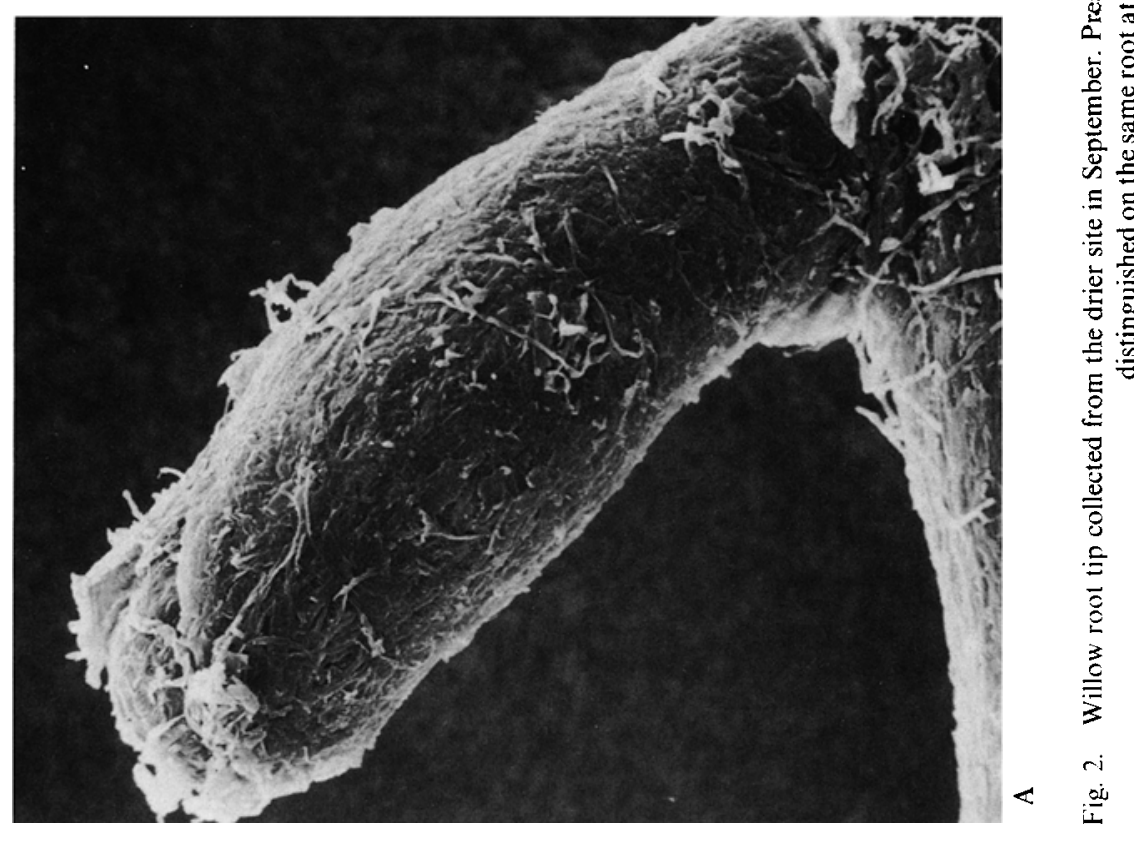




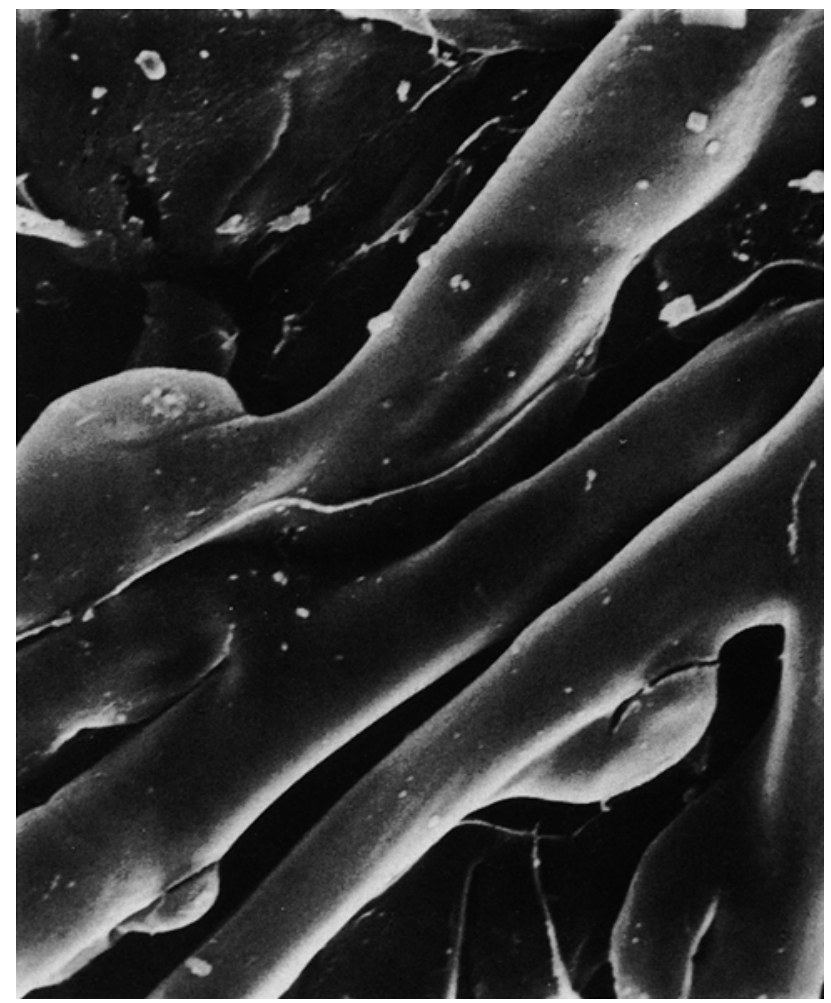

Fig. 3. High magnification of willow root showing clamp connections; collected from the wet site in September $(5000 \times)$.

$(p \leq 0.05)$ among sampling dates and among treatments (Table 1). On the wet site, roots of control plants were less intensely mycorrhizal in August than in July or September, but this late summer decline was not observed in roots exposed to added phosphorus. On the relatively drier site, mycorrhizal intensity of roots of control plants dropped in August, but it also dropped on roots of both treatments where $P$ was applied. Infection intensity increased again in September for controls, but it did not significantly increase when $P$ was applied. No difference in mycorrhizal intensity was observed between the two levels of added phosphorus (Table 1).

The phosphorus addition could have affected mycorrhizal intensity in several ways. Increased phosphorus availability could have stimulated late-season root elongation rates such that vigorous roots may have outgrown the fungi as 
described by Wilcox ${ }^{21}$ and Lamb and Richards ${ }^{10}$. Such roots may become infected as the slower-growing fungi penetrate new root tissues. Alternatively, the added phosphorus may have increased root vigor to the extent that fungal infection was resisted. Since root elongation was not measured and since fall root growth was not examined for mycorrhizal development the following season, we have no basis to speculate the cause of the observed responses to phosphorus. Our overall conclusion from this work is that if wetland soils were kept wet, as they would be with sewage effluent additions, added phosphorus had no effect on the intensity of mycorrhizal infection in wetland willow.

\section{ACKNOWLEDGEMENTS}

The authors wish to thank Profs. H. L. Morton and R. D. Fogel for their helpful comments and the staff of the University of Michigan's Matthaei Botanical Gardens for technical assistance. Financial support was provided by the U.S. Department of Agriculture.

Received 29 July 1980

\section{REFERENCES}

1 Anderson, T. F. 1951 Trans. N.Y. Acad. Sci. 13, 130-134.

2 Chamie, J. and Richardson, C. J. 1978 In Freshwater Wetlands: Ecological Processes and Management Potential. Academic Press. N.Y.

3 Coutts, M. P. and Philipson, J. J. 1978 New Phytol. 80, 71-77,

4 Fontana, A. 1962 Allionia 8, 67-85.

5 Goodwin, R. H. and Niering, W. A. 1974 Bull. Ecol. Soc. Am. 55, 2-6.

6 Grant, R. R., Jr. and Patrick, R. 1970 In Two Studies of Tinicum Marsh, Delaware and Philadelphia Counties, Pa. The Conservation Foundation. Washington, D.C.

7 Hatch, A. B. 1937 Black Rock For. Bull. 6, 168 p.

8 Johansen, D. A. 1940 Plant Microtechnique. McGraw-Hill, N.Y., 491 p.

9 Klopatek, J. M. 1978 In Freshwater Wetlands: Ecological Processes and Management Potential. Academic Press. N.Y.

10 Lamb, R. J. and Richards, B. N. 1974 Soil Biol. Biochem. 6, 167-171.

11 Maeda, M. 1954 Kumamoto J. Sci. 3, 57-84.

12 Paivanen, J. 1970 Suo. 21, 18-24.

13 Phillips, J. M. and Hayman, D. S. 1970 Trans. Br. Mycol. Soc. 55, 158.

14 Powell, C. L. 1975 Plant and Soil 142, 481-484.

15 Richardson, C. J., Kadlec, J. A., Wentz, A. W., Chamie, J. M., and Kadlec, R. H. 1976 In Proc. Third Wetlands Conf. Inst, of Water Res., Univ. of Conn. Rep. 26.

16 Richardson, C. J., Tilton, D. L., Kadlec, J. A., Chamie, J. P. M., and Wentz, A. 1978 In Freshwater Wetlands: Ecological Processes and Management Potential. Academic Press. N.Y.

17 Siegel, S. 1956 Nonparametric Statistics for the Behavioral Sciences. McGraw-Hill, N.Y. 312 p.

18 Tilton, D. L. 1977 Bull. Ecol. Soc. Am. 58, 19-20.

19 Tilton, D. L. and Kadlec, R. H. 1979 J. Environ. Qual. 8, 328-334.

20 Wentz, A. 1976 Ph.D. Diss. The University of Michigan, Ann Arbor, Michigan.

21 Wilcox, H. E. 1968 Am. J. Bot. 55, 247-254. 